\title{
Information literacy education and instruction in academic libraries and LIS schools in institutions of higher education in South Africa
}

\author{
Glenrose Velile Jiyane' and Omwoyo Bosire Onyancha ${ }^{2}$ \\ University of South Africa, Department of Information Science \\ jiyangv@unisa.ac.za; onyanob@unisa.ac.za
}

\begin{abstract}
Received: 10 January 2010
Accepted: 30 June 2010

Information literacy (IL) is increasingly becoming one of the core subjects in many LIS schools' curricula today. It is universally considered one of the effective means through which one's information skills are developed, and more especially at Higher Education Institutions (HEIs). The aim of this study is to explore the availability and implementation of information literacy programmes in South Africa, with special reference to LIS schools/departments and academic libraries. The study is largely informed by a literature review of scholarly journal articles, books and Internet sources and a survey involving LIS schools/departments and academic libraries in South Africa. Results indicate that most LIS schools and academic libraries provide IL programmes; the IL programmes are known by different titles/names; there are common as well as uncommon topics offered to students; the IL programme is largely offered to first year students by qualified LIS professionals; the purpose of offering IL programmes is generally to enable students to access, select and utilise resources effectively; the challenges of IL provision include lack of resources (e.g. staff, funds and e-laboratories) and support; and the library's and LIS departments' community engagement as far as IL provision is concerned is minimal. Several recommendations towards the improvement of IL delivery by LIS departments and academic libraries in South Africa are made.
\end{abstract}

Keywords: Academic libraries; Information literacy; information skills; technological skills; LIS schools; South Africa

\section{Introduction}

Sub-Saharan Africa suffers from a myriad problems and challenges, including poverty, hunger, disease, poor governance, ignorance, and illiteracy. At independence or liberation from the colonial masters, most African leaders saw illiteracy as one of the most challenging issues. To date, several years after African countries attained independence, illiteracy levels still remain, by and large, high. According to the UNESCO Institute for Statistics (2002), the adult illiteracy rate in onethird of the African countries ranges between $50 \%$ and $100 \%$ of the total population in the said countries. The statistical estimates further reveal that four out of ten adults in sub-Saharan Africa cannot read or write while the Hutchinson Encyclopedia (2009) reveals that Africa's illiteracy rate is the highest in the world, i.e. 54\% of the adult population. Myburgh (2009) supports the view that illiteracy is high in the region. According to the author, the main obstacles to literacy in the continent include:

- Children have very little pre-literacy training at home, or exposure to books, as their parents are often illiterate.

- There are not enough books written in the languages of Africa that are suitable for neo-literates, particularly adult neo-literates, and thus learning to read involves, at the same time, English or some other European languages.

- Many teachers are not qualified, but are simply those who have successfully passed through the school system.

- There is little opportunity to practise the newly gained skills, through lack of libraries and general high cost of books, even if they are available.

According to the Association for Progressive Communications [APC] (n.d.), Zimbabwe (90\%) tops the list of countries with high literacy rates in Africa followed by Mauritius (85.3\%), Equatorial Guinea (84.8\%), Lesotho (84.4\%), Namibia (83.3\%), Congo (Brazzaville) (82.8), South Africa (82.4\%), Libya (81.7\%), and Swaziland (80.9\%). Countries with low literacy rates include Niger (17.1\%), Burkina Faso (25.7\%), Gambia (38.9\%), Benin (39\%), Senegal (39\%), Guinea Bissau (4I\%), Ethiopia (4I.5\%), Angola (42\%), and Chad (45.8\%). It is noteworthy, however, that literacy statistics are, in most cases, grossly unreliable and therefore should be treated with caution. The most important aspect is how literacy is defined in a particular context.

That notwithstanding, the statistics indicate that South Africa's literacy rate is relatively high. Nevertheless, it has been observed that the country's functionally illiterate adults are on the increase (Aitchison \& Harley 2006) as shown in Table I. We believe that the low functional literacy rates, in sub-Saharan Africa in general and South Africa in particular, profoundly impact on the information literacy skills of the general population. Functional literacy refers to the reading and writing skills sufficient for everyday life, which implies that the less skilled the population is in reading and writing, the less

I. Glenrose Velile Jiyane is a lecturer in Information Science, University of South Africa, Pretoria.

2. Omwoyo Bosire Onyancha $(\mathrm{PhD})$ is a senior lecturer in Information Science, University of South Africa, Pretoria. 
information literate the population is likely to become as these skills, among others, define the characteristics of an information literate person.

Table I Literacy and basic education levels of South Africans aged I5 and over

\begin{tabular}{|l|l|l|l|}
\hline \multicolumn{1}{|c|}{ Level of Education } & I995 October Household Survey & I 996 General Population Census & 200I General Population Census \\
\hline Full general education (Gr. 9 and more) & I4.3 million (54\%) & I3.I million (50\%) & I5.6 million (52\%) \\
\hline $\begin{array}{l}\text { Less than full general education (less } \\
\text { than Gr. 9) }\end{array}$ & 12.2 million (46\%) & 13.2 million (50\%) & 14.6 million (48\%) \\
\hline Less than Gr. 7 & 7.4 million (28\%) & 8.5 million (32\%) & 9.6 million (32\%) \\
\hline No schooling & 2.9 million (I I\%) & 4.2 million (I6\%) & 4.7 million (I6\%) \\
\hline
\end{tabular}

Source: Aitchison \& Harley (2006)

\section{Information literacy: a brief overview}

The concept of information literacy (IL) was introduced in 1974 by Paul Zurkwski in a proposal submitted to the National Commission on Libraries and Information Science (NCLIS), recommending that a national programme be established to achieve universal information literacy (Eisenberg, Lowe \& Spitzer 2004:3; De Jager \& Nassimbeni 2002). Behrens in De Jager and Nassimbeni (2002:167) clarifies that during the 1980s this term gradually started to replace the concepts of user education and library skills. According to McCaskie (2004:9), the first advocates of IL were mainly school librarians in the U.S., but it was not until the 1980s that the use of the term and the concept became more widespread. The personification of the concept IL is stipulated in McCaskie (2004:9) who exposes its importance by giving the significant events of its lifespan which includes the establishment of the American Library Association's (ALA) Presidential Committee on the Information Literacy (PCIL) in 1987 and its subsequent report which followed in 1989. While emphasising the importance of IL, the PCIL report links IL to the goals of lifelong learning and effective citizenship.

There are several definitions of IL, none of which is universally applicable. Nonetheless, the American Library Association provides what has come to be recognised as an all-encompassing definition of an information literate person. The Association describes an information literate person as "one who recognizes when information is needed and has the ability to locate, evaluate and use effectively the needed information" (ALA 1989; 2000). According to the United Nations Education, Scientific and Cultural Organization [UNESCO] (2008:2), IL refers to one's ability to:

- Recognise his/her information needs.

- Locate and evaluate the quality of information.

- Store and retrieve information.

- Make effective and ethical use of information.

- Apply information to create and communicate knowledge.

Opinion is divided on whether IL is a new concept or it is merely a progression from the library instruction that has been in existence since the 1960s (Grassian \& Kaplowitz 200I). The traditional role of libraries as custodians of information sources is slowly changing. Johnson \& Webber (2003) observe that libraries are increasingly regarding themselves as teaching institutions which can assist students in their learning process. Wright (2007) agrees with this view by observing that libraries have changed over the last 25 years, especially with the emergence of information technology. Not only has the means of accessing information changed but also the format in which information is stored and made available.

Information is now available in multimedia formats such as CD-ROMs, e-journals, the Internet and e-databases. In view of these advancements, librarians are urged to embrace other duties such as those outlined by Wright (2007): teaching the library users to determine their information needs, help users locate and access authoritative information and help them understand how to use the information ethically. Rockman (2006: I) however argues that IL is no longer a library issue, but is the critical campus-wide issue in the twenty-first century. The importance or necessity of IL in the information age is underscored by Adeogun (2003) and Rockman (2006). According to Adeogun (2003:12), the new world order characterised by abundance and ready availability of digital information through computer networks means that information has become ubiquitous, and therefore can be obtained at any time and in any location no matter the distance as long as the necessary infrastructural devices and the skills to retrieve information from global networks are available. She further observes that the use of the internet has revolutionised the education sector, making a formal education system more versatile and flexible. Rockman (2006: I) observes that the increasingly complex world in which we live now contains an abundance of information choices - print, electronic, image, spatial, sound, visual and numeric all of which indicate the availability of too much information in various formats with un-equal value. The need for tertiary graduates to acquire and develop information literacy skills has been emphasised in recent years in a world where, many analysts believe, access to information is not only important for survival but the key to prosperity (Feast 2003: 8I).

SA Jnl Libs \& Info Sci 2010, 76(I) 
For successful IL programmes in institutions of higher learning, Fourie (1999:383) states that students' attitudes towards information foraging and use require total change. Similarly, Harrison and Rourke (2006:605) state that the integration of information literacy into university curricula is possible through the understanding between the librarians, students and faculty. Skagen, et al., (2006:5) too, see collaboration between the libraries and academic departments as an exercise that can be used to assist students. True collaboration, according to the authors, is based on shared goals which the parties have negotiated and made explicit; calls for a 'contract' between the parties, or a strategy plan, where each part's responsibilities and competencies are made clear and recognised; and takes place at all levels within a higher education institution. Both a bottom-up and a top-down approach to true collaboration are necessary.

\section{IL programmes/projects in South Africa}

When South Africa formed a Government of National Unity in 1994, after decades of the apartheid regime, the provision of education to all the citizens with a view to improving their literacy level was seen as a priority. Before 1994, the education system in the country had been segmented, with the white population having access to better educational opportunities and resources. This situation afforded a minority of the South African populace better literacy and information handling skills. The majority of South Africans, therefore, suffered from a lack of or poor formal education which largely affected their ability to read and write. Underwood, Nassimbeni \& De Jager (2002: 5) explain that information literacy was identified as a key part of the solution to weaknesses in regard to access to information and the management of information resources.

To this end, several information literacy projects were initiated in the country with a view to increasing the level of literacy, particularly in the current information age. According to De Jager and Nassimbeni (2002:168), the interest in information has been spurred by systematic transformation of education at all levels and the increasing adoption of ICTs in the South African society and as a result, the policy framework for IL in tertiary institutions is based on three policy domains, namely: education policies, ICT policies and library and information service policies. The following is a list of some of the IL projects/initiatives that were started in the country:

a. The Western Cape Library Cooperative Project was initiated in 1992 and carried out with the view of promoting IL and economic development for the Western Cape Province by providing information to users in the form they wanted and when and where they needed it (Underwood 2000: 16).

b. In 1995, the INFOLIT project was established in the country. According to De Jager, Nassimbeni and Underwood (2007: 159) its main aim was to promote the concept, value and importance of IL in the context of globalisation. This project was to launch a series of pilot projects which explored and established various means of offering IL education in the region and to investigate IL models, programmes and initiatives in other countries.

c. Zinn in Underwood, Nassimbeni and De Jager (2002:8) reports that there have been initiatives aimed at inculcating IL into the curriculum of the primary and secondary school systems. These initiatives emphasise the role of the teacher in society, where teachers, as lifelong learners, have to be numerically, technologically and media literate.

d. The LINK centre at the University of Witwatersrand is one of the IL programmes in place in the country. The University works with the community and offers certified courses on IL (Underwood, Nassimbeni \& De Jager 2002).

e. Finally, the Government of South Africa, through the Department of Education, established a project known as Technology Enhanced Learning Initiative (TELI), which focuses on the use of ICTs and the development of skills to use ICTs (de Jager \& Nassimbeni 2002: 170). The authors further state that one of the projects that relates to TELI is to develop a generic IL course to be used in schools, community centres, industry-based training sites and other appropriate sites of teaching and learning. This initiative clearly spells out that the information handling skills need to be introduced in the early years of and throughout schools so that the learners are able to collect, analyse, organise and evaluate information at an early school career level.

Although some of the aforementioned initiatives or projects have faced several challenges in their implementation, there are noticeable achievements. For instance, according to Underwood (2000:17), there is considerable evidence that the INFOLIT Project achieved several of its objectives. The project is said to have created awareness of the potential of IL amongst librarians and the academic staff. Underwood further observes that INFOLIT has necessitated several workshops in which issues such as educational transformation, redress and the impact of ICTs on the 'learning space' are also discussed. As a way of improving IL among family members through functional literacy programmes, one other project that is said to have had a tremendous impact on the community in Gauteng Province is the Family Literacy Project which was set up by the Children's Literature Research Unit (CLRU) at UNISA in cooperation with Project Literacy, a Non-Governmental Organization (Machet and Wessels 2006: 60). The aim of the project was to teach neo-literate or illiterate parents or caregivers to read stories to pre-schoolers to develop emergent or pre-literacy skills (Machet \& Wessels 2006: 60). As a 'partner' with the much needed information, human and/or financial resources was essential for 
long term sustainability of the project, public libraries were co-opted as partners (Machet \& Wessels 2006: 60). Among the project's positive results, according to Machet and Wessels (2006:69), is the reinforcement of the parents' literacy skills. The authors, nevertheless, observed that it takes time and sustained action over an extended period to make any fundamental change in respect of improving family literacy. Similar studies to this were conducted in 2002 and 2005 by De Jager and Nassimbeni $(2002 ; 2005)$ to assess the progress made in the institutionalisation and inculcation of IL in higher institutions of learning in South Africa. Initially, it was reported by the authors that institutional commitment was lacking, but later the authors noted remarkable progress, especially on the part of the academic libraries which made reference to $\mathrm{IL}$ in their mission statements.

\section{Purpose of the study}

As a follow-up to De Jager and Nassimbeni's $(2002$; 2005) studies, this study seeks to explore the availability and implementation of information literacy programmes at higher institutions of learning in South Africa, with special reference to the library and information science/studies (LIS) schools and academic libraries in order to:

- Establish the mode in which IL is offered;

- Discover the purpose of offering IL programmes in South African universities;

- Determine the qualifications of persons charged with offering IL programmes;

- Establish the academic level at which IL programmes are offered;

- Identify the core topics taught or learnt in IL programmes;

- Identify the challenges facing LIS schools and academic libraries in the provision of IL programmes;

- Assess the LIS schools' and libraries' engagement in the provision of IL to the communities in their environments.

\section{Methodology}

Two methods were employed to conduct this study, namely:

(a) literature review; and

(b) a survey.

On the one hand, the study was informed by a review of the relevant literature which was in the form of journal articles, books, project reports, and magazine and newspaper articles. The literature review approach was used to gather data on the development of IL as a concept as well as identify the various IL projects initiated and/or implemented in South Africa.

On the other hand, a descriptive survey method, based on a qualitative research design, was chosen on the basis that it typically seeks to ascertain respondents' perspectives or experiences on a specified subject in a predetermined structured manner. All 23 universities in South Africa were selected for the study. The study targeted two groups of people, namely: heads of LIS departments and librarians in charge of IL instruction in the South African universities. The universities' websites were browsed in order to obtain:

a. A list of LIS departments/schools and the contact details of the chairs of departments/schools (CoDs).

b. Contact details of the directors or librarians responsible for IL training at the main libraries. It is worth mentioning that after the merger of South African universities in 2004, the administration structure of university libraries was also affected. For instance, some libraries that had been main institutional libraries became constituent libraries of others. Only the main libraries were included in this study.

Where the above information was not readily available on the websites, contact was made with CoDs whose contact information was known to the researchers. The CoDs were asked to provide the researchers with either e-mail addresses or telephone numbers of the CoDs whose information was not available on the university websites. Some LIS schools (e.g. the LIS department at the University of Fort Hare) did not have a website.

In total, we obtained a list of 12 LIS schools' CoDs and 21 academic librarians. A questionnaire, consisting of 17 openand closed-ended questions for each group was then compiled and sent to the CoDs and library directors who were asked to pass them on to the persons directly charged with IL instruction in their respective departments. The information sought in the questionnaires included:

a. The title/name of the module/course

b. Whether or not IL is offered as a formal or informal module/course

c. Purpose of the module

d. Academic qualifications of the person charged with offering IL

e. The content (i.e. topics) of IL modules/courses

f. Level at which IL is offered

g. Frequency of offering IL programmes

h. Duration IL instruction/education takes

i. Opinion on whether or not IL should be offered by non-LIS professionals 
j. Challenges of offering IL

k. IL programmes for the community around the respective universities

l. Suggestions on the improvement of IL offerings

Out of the 23 questionnaires that were distributed to the libraries, only 5 were returned, accounting for a $23.8 \%$ response rate. Follow-up telephone calls were made with regard to the libraries that had not responded by the due date that we had set for our study. Most library respondents were said to be either away from the office or busy whenever we called, a situation that explains the low response rate. The libraries that responded to the questionnaires were: the University of Zululand (UZ), University of South Africa (UNISA), Stellenbosch University (SUN), University of Pretoria (UP), and Nelson Mandela Metropolitan University (NMMU) library. On the part of the LIS departments, a total of eight out of ten (9/12) departments responded, thereby accounting for a $75 \%$ response rate. The LIS departments that responded are: University of Zululand (UZ), University of South Africa (UNISA), University of Pretoria (UP), University of Cape Town (UCT), University of the Western Cape (UWC), Walter Sisulu University of Technology (WSU), University of Johannesburg (UJ), University of KwaZulu-Natal (UKZN) and the Durban University of Technology (DUT).

The collected data was qualitatively analysed and presented in graphical formats using Microsoft Excel @C2003.

\section{Results and discussion}

This section provides and discusses the findings according to the questions posed to the respondents as indicated in the methodology section.

\subsection{Title/name of module}

The title of the module, as is the case with any title (e.g. titles of publications, persons, etc.), ordinarily indicates the content or rank of an entity, among others, albeit partially. With a view of gaining an understanding of the titles given to IL programmes, we found that academic libraries' IL programmes are known by different names such as library orientation, user education, computer training and library catalogue training. User education and library orientation have for a long time constituted the core methods by which IL are offered in libraries. The introduction of computer-related titles such as computer training introduces a new area in IL especially in the information age, namely computer literacy skills. It was assumed that the catalogue training mentioned by some libraries refers to the training offered by the libraries to the library patrons on the use of the traditional card catalogue or the Online Public Access Catalogue (OPAC) in accessing and retrieving library materials. On the part of LIS departments, the IL titles/names included information literacy programmes, information science and literacy, developing information skills for life-long learning, information literacy, library science, and information literacy education. Clearly, the titles given to IL programmes by LIS departments reflect the subject domain. The exception is library science. One title that stands out in its reflection of UNESCO's view of IL is developing information skills for life-long learning. UNESCO (2009) outlines its strategy thus: 'UNESCO's main strategy in the area of information literacy consists of awareness-raising about the importance of information literacy at all levels of the education process - basic education, primary and secondary education, technical and vocational training and lifelong education - and of establishing guidelines for integrating information literacy issues in curricula".

\subsection{Mode of IL delivery}

The LIS departments' respondents were asked to indicate whether the IL programmes in their respective institutions were offered as a formal qualification or non-formal programme. In case none of the above applied, the respondents were provided with an option to specify the mode of provision. True to our expectation, most LIS departments offer IL as formal modules and are embedded in their curricula. Nevertheless, a few departments revealed that they teach IL as topics within broader modules. For instance, the Durban University of Technology and the University of Cape Town indicated that IL is taught as topics in different modules or within other subjects. Although the modules within which IL is taught were not specified by UCT, DUT indicated that IL topics are integrated within such subjects as information retrieval which is one of the major subjects offered to third-year level students of the National Diploma and encompasses aspects such as the use of bibliographic tools in accessing information and evaluating information sources.

The approach of integrating IL as topics within different modules may have both good and bad results. For instance, the subjects within which IL is integrated may receive greater attention than IL which is so necessary in lifelong learning. At the same time, integrating it in many subjects may cause every IL instructor to create an awareness of the importance of IL in the student's academic career and beyond. Stellenbosch University indicated that it is only in Legal Skills $4 \mathrm{II}$ and Introduction to Law I7I where IL aspects are not taught, as these two are credit-bearing curriculum-integrated modules. The other modules which are not credit-bearing have modalities through which IL topics are offered and evaluated, e.g. in the assessment of assignment outcomes. The LIS department at the University of South Africa revealed that besides offering formal IL education to students, they also offer non-formal instruction on the use of computers and selected computer software to LIS students using the departmental information (computer) practise centre (IPC).

SA JnI Libs \& Info Sci 2010, 76(I) 
On the other hand, the libraries indicated that IL is largely offered as a non-formal instruction programme which mainly focuses on user education, computer skills and orientation of the library users to various services and products that the library offers. These instructional programmes offered by libraries do not lead to any formal qualification, as was expected by the researchers.

\subsection{General purpose of offering IL programmes}

In order to establish the reasons for offering IL programmes by the academic libraries and LIS departments in South Africa, the respondents were asked the question: What is the general purpose for providing IL programmes in your department? Essentially, IL programs are offered in order to enhance the learners' knowledge-base and skills in regard to information. This principle is reflected in what characterises a literate person. In its Information Literacy Competency Standards for Higher Education report, the ALA (2000) states that an information literate individual is able to:

- Determine the extent of information needed;

- Access the needed information effectively and efficiently;

- Evaluate information and its sources critically;

- Incorporate selected information into one's knowledge base;

- Use information effectively to accomplish a specific purpose;

- Understand the economic, legal, and social issues surrounding the use of information, and access and use information ethically and legally.

To that end, academic libraries in South Africa that participated in the study offer IL programmes in order to:

- Enable students to access, select and utilise resources effectively;

- Market the library and its services and resources;

- Teach students how to find correct information, evaluate it, understand the legal implications when using information; and

- Assist students in writing their assignments.

Similarly, the LIS departments indicated that IL programmes are offered so as:

- To enable students to identify their information needs; find, and retrieve relevant information; and evaluate and responsibly use information;

- To attract more students;

- To equip students with knowledge and skills that can enable them to design and offer IL programmes as trainers; and

- To equip the would-be information workers with skills to provide information services effectively.

The idea of using IL programmes to attract more students deserves brief explanation. Current trends in most institutions of higher learning dictate that departments' or programmes' continued existence or funding has to be justified, especially in this era of limited financial resources and competitive economic environment. It is worth mentioning that some LIS schools/departments in the country have closed down, most probably because they were not self-sustaining. Indeed, in most universities, IL programmes have become so popular to an extent that they have become to be categorized together with what has become to be popularly known as 'power courses or programmes or modules'. The term 'power course/module/programme' refers to courses/programmes/modules in which students register in their thousands.

It was established that some LIS schools such as UCT and UP have adopted the train-the-trainer approach in the provision of IL programmes. In the case of UP, a few students are identified and trained in order to offer IL programmes to other students registered for the programmes while UCT trains learners who are expected to impart the acquired skills and knowledge to the community where they will be working upon the completion of their studies. As shortage of staff to handle large numbers of students enrolled for IL programmes in various LIS schools in the country is critical, the approaches adopted by UP should be applauded as long as quality of programme delivery is assured.

\subsection{Qualification of instructors}

It is imperative that students taking any academic programme or qualification are well guided in their studies by qualified staff. IL programmes are not an exception. To that end, the following question was asked in relation to the qualification of the IL instructors:

What are the highest academic qualifications of the person(s) charged with the responsibility of offering the IL programme?

This question was posed to the respondents in order to determine the academic qualifications that IL instructors posses or should posses in order to successfully offer IL programmes. The respondents were provided with the following options: Matric; First Degree in LIS; First Degree in another field; Masters degree in LIS; Masters Degree in another field; Doctoral degree in LIS; and Doctoral degree in another field. In the case of any other qualification, the respondents were asked to specify, accordingly. Broadly speaking, all the LIS schools surveyed have qualified staff in place to deliver IL programmes. Of the 9 respondents from the LIS departments, there were 2 holders of a first degree in LIS; 3 holders of 
a Masters degree; and 3 holders of a doctorate. The remaining institution (i.e. UP) indicated that all the module managers have postgraduate degrees. In addition to the module managers, the LIS department at UP makes use of assistant lecturers who are holders of a three-year Bachelor's degree and enrolled at the university for Honours or Masters degrees. These assistant lecturers are intensively trained by the module managers before undertaking the delivery of IL programmes. This approach of IL delivery is necessitated by the fact that UP has over 7000 students registered for the module. The UP initiative is a good example of managing IL programmes in situations where there are large numbers of students involved. UNISA's policy in situations similar to UP's is to adopt the use of markers and tutors whenever the number of students is large.

\subsection{Content of IL programmes}

On the question of what topics or areas are covered in the IL programmes, the responses varied from one institution to another. Whilst some respondents outlined the subject content of the IL programmes offered in their respective departments/schools, others simply indicated that the list of topics/subjects was either too long to be put on paper or could not simply be provided for some unexplained reasons. We therefore used UP's outline which was comprehensively prepared and appropriately inserted other LIS schools' topics in the former's list (see Appendix I). There were several similarities among the topics taught in various LIS schools. It was observed that the majority of topics offered in IL programmes in South Africa conform to the American Library Association's (ALA) information literacy competency standards for higher education (ALA 2000). ALA (2000) outlines the standards and performance indicators for and outcomes in each standard. ALA's standards and performance indicators include:

I. The information literate student determines the nature and extent of the information needed.

a. The information literate student defines and articulates the need for information.

b. The information literate student identifies a variety of types and formats of potential sources for information.

c. The information literate student considers the costs and benefits of acquiring the needed information.

d. The information literate student re-evaluates the nature and extent of the information need.

2. The information literate student accesses needed information effectively and efficiently.

a. The information literate student selects the most appropriate investigative methods or information retrieval systems for accessing the needed information.

b. The information literate student constructs and implements effectively-designed search strategies.

c. The information literate student retrieves information online or in person using a variety of methods.

d. The information literate student refines the search strategy if necessary.

e. The information literate student extracts, records, and manages the information and its sources.

3. The information literate student evaluates information and its sources critically and incorporates selected information into his or her knowledge base and value system.

a. The information literate student summarizes the main ideas to be extracted from the information gathered.

b. The information literate student articulates and applies initial criteria for evaluating both the information and its sources.

c. The information literate student synthesizes main ideas to construct new concepts.

d. The information literate student compares new knowledge with prior knowledge to determine the value added, contradictions, or other unique characteristics of the information.

e. The information literate student determines whether the new knowledge has an impact on the individual's value system and takes steps to reconcile differences.

f. The information literate student validates understanding and interpretation of the information through discourse with other individuals, subject-area experts, and/or practitioners.

g. The information literate student determines whether the initial query should be revised.

4. The information literate student, individually or as a member of a group, uses information effectively to accomplish a specific purpose.

a. The information literate student applies new and prior information to the planning and creation of a particular product or performance.

b. The information literate student revises the development process for the product or performance.

c. The information literate student communicates the product or performance effectively to others.

5. The information literate student understands many of the economic, legal, and social issues surrounding the use of information and accesses and uses information ethically and legally.

a. The information literate student understands many of the ethical, legal and socio-economic issues surrounding information and information technology.

SA Jnl Libs \& Info Sci 2010, 76(I) 
b. The information literate student follows laws, regulations, institutional policies, and etiquette related to the access and use of information resources.

c. The information literate student acknowledges the use of information sources in communicating the product or performance.

In view of the above mentioned standards and performance indicators, LIS schools and libraries in South Africa offer a variety of topics in their delivery of IL programmes. These topics range from the definition of IL and related concepts to the current trends associated with ICT-related IL topics. Broadly speaking, the LIS schools' IL curriculum includes information sources and resources, Internet and the World Wide Web, searching databases and online journals, organization and retrieval of information, ethics and use of information, referencing and referencing techniques, evaluation of information and resources, writing skills, and communication technologies (e.g. Web 2.0 and Library 2.0). On the part of academic libraries (see Appendix 2), IL topics include orientation in the library (e.g. library etiquette, procedures for borrowing, returning and renewing books, study collection: recommended books, introduction to the classification schemes used by libraries, how to find a book on the shelf, identifying title, author and edition of a book, and using the table of contents and index); how to become knowledgeable in the usage of essential additional information and reference sources in the library; how to use the library and its resources effectively; basic mouse and keyboard skills; and the Internet (e.g. using the Internet, searching the Web and using Web mail). These findings are contrary to the findings reported by Rasaki (2008) who found that "in many universities [in Africa] that offer the course for credit, the emphasis is on library and reading skills with utter neglect of computer and technology literacy". Citing Dulle (2004), Rasaki reports that universities in Africa practice mainly user education and library orientation. The author further noted that the "unit and status of the course is not enough to achieve the desired results".

\subsection{Study level of IL offering}

At what academic level should IL programmes be offered to university students? In response to this question, most respondents, that is seven indicated that it should be mandatory for all first year level students to undertake the IL programmes as high school graduates that are joining universities for the first time have very little (if any) IL skills. Two respondents felt that IL programmes should be offered to all categories of students (i.e. First, Second, Third, Fourth and Post-Graduate). Three respondents, however, suggested that these programmes are more relevant to post-graduate students only. The argument fronted by the latter group of respondents is that post-graduate students' studies are largely research-oriented, a situation that demands information foraging, retrieval and use skills.

\subsection{Frequency and duration of IL delivery}

Three questions were posed to the respondents, namely:

- How often the IL programme is offered in their respective departments;

- The time or duration the programme takes to be completed; and

- Whether or not the duration above is enough.

As expected, the frequency of IL delivery differed from one department to another. Of the departments that responded to this question, 2 indicated that their IL programmes are offered as semester courses while one respondent indicated that the programme is offered only in the $2^{\text {nd }}$ semester. The IL programme at UCT is offered in two phases as follows: topics (i.e. theory part) are introduced in the first semester while the practical part is offered in the second semester. On the part of libraries, most of them provide IL training sessions four times in a year (i.e. quarterly) while some indicated that the frequency sometimes depends on the requests they receive from academic departments.

How long does a complete IL programme/course take? Varied answers were offered in regard to this question. Most departments, that is, five indicated that IL programmes/courses are offered for a period of more than four weeks. The IL programme at UCT is offered for less than a week. In the case of libraries, IL programmes' sessions are less than one week long. This contrast was expected as libraries do not provide IL instructions as part of an academic qualification, in which case the duration could be longer. In addition, libraries' IL content is not as elaborate as the teaching departments/ schools.

When further asked whether or not the duration within which IL programmes are offered in their respective departments was enough, all - except one - respondents (including the libraries) felt that the time allocated for students to complete the programme was adequate. The UWC felt that the time allocated, that is, four weeks was inadequate and suggested that the course should take a whole year because the students would require more time to master and apply information literacy skills. The respondent from UWC further argued that a whole year will guarantee better writing and cognitive skills on the part of students, majority of who are ill prepared for university education. 
6.8 Should IL programmes be offered by non-IL specialists?

As the IL content consists of interdisciplinary topics (e.g. writing skills [communication science or language studies], computer literacy skills [computer science], etc), this question was deemed necessary to gauge the perception among LIS workers to the effect that IL programmes should be offered by LIS workers only. Indeed, all academic libraries indicated that only persons with LIS qualifications can successfully offer IL programmes. Similarly, on the part of the LIS departments/schools, a high number, that is seven indicated that IL programmes are better off offered by LIS professionals. Three respondents (particularly from the LIS departments' category) however felt that in some instances a higher degree in any other discipline may compliment the first qualification in LIS. For instance, the UKZN argues that aspects like training students on how to search the Web can conveniently and effectively be done by a non-LIS specialist (e.g. computer scientist or Web developer). On its part, the UP indicated that their IL module is taught by non-LIS specialists. As aforementioned, due to the large number of students enrolled for the IL module, the department of information science at UP appoints and trains post-graduate students who are then mandated to deliver IL programmes using study materials (including slides, assignments and examinations) compiled by staff members in the department. Arguably therefore most LIS professionals would prefer to have LIS-specialists engaged in the delivery of IL programmes, except for rare situations such as those offered by UP.

6.9 Challenges of IL delivery

A number of challenges that the university libraries and LIS departments in South Africa face were identified as follows:

a. Academic libraries noted that:

- Students who join universities for the first time lack basic information handling skills, including basic computer skills. Most students come from poorly technologically equipped schools and therefore are poorly equipped to use computers for purposes of accessing information that is largely available electronically. This means therefore that IL teachers are forced to begin the lessons at very basic levels. One institution indicated that some students do not even know how to hold a mouse.

- The main dilemma is how to attract most students to attend IL instruction sessions as the programme is not mandatory. Because the programmes are offered for non-degree purposes, students tend not to take them seriously and hence do not realise the importance of participating in the sessions resulting in minimal development of their IL competencies and skills. This response is in line with the observation made by Haycock (2000) and Brown, Murphy and Nanny (2003) that students are busy and if they do not see any immediate need to attend the IL sessions, they will not. Worse still, some students do not believe that they lack these skills, and thus do not see the need for training.

- There is lack of resources necessary to successfully offer IL programmes. The ever shrinking university budgets have resulted in shortages of staff and the relevant facilities such as computers and computer laboratories.

b. LIS departments/schools' challenges include:

- Student apathy: As was the case with academic libraries, there is very little interest in IL programmes, particularly from those students enrolled in other disciplines other than LIS. This scenario is however changing as some LIS departments/schools (e.g. UNISA, UNIZUL and UP) reported that students from other disciplines are now registering to attend IL sessions.

- Low student enrolment: Generally, there is low student enrolment in LIS departments when compared to other disciplines within the respective universities. It is from this pool of few students that IL programmes draw its students, especially in situations where students from other disciplines do not enrol for IL lessons.

- Lack of resources: The provision of equipment and facilities such as e-laboratories and e-classrooms with enough working computers to offer IL programmes is not adequate. In addition, there are no extra staff members to spare for non-formal IL programmes. The teaching staff in some institutions (UP and UNISA) is overstretched by large student enrolments in IL programmes. For instance, UP has 7000 students in the programme while UNISA's programme attracted a total of 4000 students in 2009.

$6.10 \mathrm{IL}$ programmes for the communities

Community engagement or service is one of the key functions of universities in South Africa. In fact, all universities in the country have embedded this aspect in their policy documents. Some institutions such as UNISA have established departments that deal with the staff's community engagement and outreach (i.e. UNISA's Department of Community Engagement and Outreach). One of the key performance areas (KPA) used to evaluate staff performance and for purposes of recruitment, promotion and tenure is community engagement. Furthermore, as indicated from the introductory matter, the South African populace lacks information skills. In that regard, the respondents were asked to indicate whether or not their departments (especially the LIS departments) engage themselves in community service as a way of improving the South African community's IL skills and competencies. The assumption was that academic libraries and LIS schools/departments have got a role to play in improving a given community's IL skills through workshops and other projects. 
It was noted that a high percentage of academic libraries (75\%) and LIS departments $(60 \%)$ do not engage in community activities as far as the provision of IL programmes are concerned. Nevertheless, of the academic libraries that responded to the question, it was established that only the University of Stellenbosch (SUN) has a programme through which it offers basic IL instruction to the surrounding primary school learners. On the part of LIS departments, there are a few community-based programmes/projects in place. For instance, the Department of Information Science at UNISA runs a family literacy programme in Gauteng province where it is engaged in encouraging and instilling reading culture and information handling skills among different families. Some IL activities are also carried out through workshops and seminars. The LIS department at UNISA indicated that it has conducted IL seminars and workshops to information practitioners in Eastern Cape and North West provinces while the UCT department have done the same in Mpumalanga province. These programmes are offered upon request from the host government departments.

\subsection{Suggestions to improve IL delivery}

As providers of IL programmes, the respondents were asked to give suggestions on how the programmes at HEls and to the community in their locality could be improved. Suggestions from academic libraries were as follows:

- The teaching staff in various departments/disciplines should support IL programmes offered by libraries by, for example, popularizing the programmes among their students. The attendance of the IL sessions in the library can be improved if lecturers told their students how valuable the programmes are in their studies.

- There is need to integrate IL programmes into the curriculum, particularly in institutions that have not done so. In that way, the IL programmes would be taken more seriously by students.

- Participation in the programme should be made mandatory for all first year students.

- More library staff members should be hired in order to support the provision of IL programmes.

On their part, LIS departments suggested the following:

- Libraries should popularize their IL programmes among lecturers as most lecturers indicated that they were not aware that the libraries are offering any IL programmes. They indicated that libraries provide superficial instruction in the form of library orientation to students as regards to the services and products available for students. According to the respondents, in order for the programme to be more meaningful, libraries should offer more than mere library orientation. The respondents suggested such topics/issues as plagiarism, copyright, citing and referencing consulted sources, computer literacy skills, database searching, organization of retrieved information, evaluation and use of information, etc. Ironically, libraries indicated that, among the issues they tackle in the IL programmes are the aforementioned.

- IL should be taught as a stand-alone module. In that way, the module's impact and success can be monitored and evaluated. This recommendation is contestable as others would feel that including IL topics in other modules will ensure that a wider student population will be reached.

- IL programmes and/or topics should be integrated into all modules of other disciplines. Alternatively, the IL module should be made mandatory for all students irrespective of the discipline of specialization.

- More resources (e.g. financial, computer facilities such as e-laboratories, and personnel) should be committed to make the programme successful.

\section{Conclusions and recommendations}

The provision of IL programmes and training sessions by academic libraries and LIS departments in South Africa, both for qualification and non-qualification purposes, indicates that there are concerted efforts towards the realization of an information literate society in the country. The programmes go by different titles/names such as library orientation, user education, and computer literacy [in the case of libraries] while LIS departments refer to the IL programmes as developing information skills for lifelong learning, information literacy, library science and information literacy education. An examination of the content reveals that there are more similarities in the IL programmes than there are differences. The core topics offered include: the definition of IL; indicators of a literate person; assessing IL; skills; technology; resources; plagiarism; etc. This indicates that the LIS programmes in South Africa, across the institutions, are geared towards applying what is done worldwide when one compares the topics covered with standards set by the ALA. Although the ALA is not a South African association, one can draw valuable lessons from it.

The participation of the libraries and LIS departments in community IL delivery is minimal. This is an area, we believe, that is ripe for IL education as South African government through its Department of Arts and Culture, provides conditional grants for the purposes of training library workers through workshops, seminars, etc. We are cognisant of the fact that one is not supposed to be paid for his/her community engagement but one can benefit from the funds especially in regard to the preparation of teaching materials, transport fees and issuance of certificates of attendance.

It was noted that librarians and LIS lecturers complained about each others' lack of support as well as ignorance about the IL programmes each party offers. The situation reveals that there is lack of cooperation between the two parties as 
far as the provision of IL programmes is concerned. Several authors (e.g. Behrens as cited in Lwehabura and Stilwell 2008) have underscored the importance of involving the teaching staff in the planning and development of IL programmes that are offered by libraries. Lwehabura (2007:166) opines that "librarians should make efforts to ensure that they involve teaching staff in IL activities, including teaching and designing or proposing IL programme content". We add that the teaching staff should encourage the students to actively participate in the library's IL sessions. It is our conviction that the teaching staff should also involve the librarians when designing or delivering their IL programmes. We believe that librarians have so much to offer especially if they have long working experience.

In regard to the level of study at which the IL programmes should be offered, it was generally observed that the programmes should be offered to all first year/level students as these students enter the universities with little or no IL skills. Although, this is the general feeling, it is our recommendation that the IL programme be delivered in phases structured as basic, intermediate and advanced IL education and instruction, particularly in the case of undergraduate programmes. Respectively, the basics of IL should be offered during a student's first year in university; the intermediate content should be taught at second level of a student's study; and the advanced IL skills programme should be delivered during the student's final year. In the case of post-graduate programmes, the IL programme may consist of intermediate and advanced courses that are specifically structured for post-graduate students.

As most respondents suggested, IL should be taught as stand-alone modules by the LIS departments. Having said that, it is imperative that the module consists of topics that reflect the current trends in information creation, storage, retrieval, dissemination and use. For instance, information is becoming increasingly available electronically, a situation that poses new challenges in accessing, storing and correctly citing the consulted electronic sources. In addition, a unified approach should be sought for purposes of formulating specific standards to which all IL programmes in the country should adhere. Perhaps, that is where the Library and Information Association of South Africa (LIASA) comes in. The association should follow its American counterpart's (i.e. ALA's) example. ALA's (2009) information literacy competency standards for higher education outlines five standards, the performance indicators of measurement and the outcomes of each of the standards. A similar approach should be adopted in the provision of IL programmes in universities in South Africa.

Finally, as this study does not offer an exhaustive report about the IL initiatives, programmes and projects that are being undertaken in the country, it is recommended that a comprehensive audit be regularly conducted to, among others, identify the number of projects, determine the target populations, and examine their impact with a view of making informed decisions with regard to their efficacy and viability.

\section{Acknowledgement}

The authors wish to thank all who participated in this survey, without whom this valuable information could have not been shared through this publication. The reviewers' input is hereby also acknowledged.

\section{References}

Adeogun, M. 2003. The digital divide and university education systems in Sub-Saharan Africa. African Journal of Library, Archives and Information Science, I 3(I): I I-20.

Aitchison, J. \& Harley, A. 2006. South African illiteracy statistics and the case of the marginally growing number of literacy and ABET learners. Journal of Education,_9:89- II 2.

American Library Association (ALA). 1989. Presidential Committee on Information Literacy: final report. [Online]. http:// www.ala.org/ala/mgrps/divs/acrl/publications/whitepapers/presidential.cfm. Accessed June 182009.

American Library Association (ALA). 2000. Information literacy competency standards for higher education. [Online]. www.ala.org/ala/mgrps/divs/acril/standards/standards.pdf. Accessed 25 February 2009.

Association for Progressive Communications (APC). n. d. APC Africa ICT policy monitor: compare national ICT statistics. [Online]. http://africa.rights.apc.org/index.shtml?apc=se_I. Accessed 25 October 2009.

Brown, C., Murphy, T.J. \& Nanny, M. 2003. Turning techño-savvy into info-savvy: authentically integrating information literacy into the college curriculum. The Journal of Academic Librarianship, 29(6):386-398

De Jager, K. \& Nassimbeni, M. 2002. Institutionalizing information literacy in tertiary education: lessons learned from South African programmes. Library Trends, 5 I (2): I67-I84.

De Jager, K. \& Nassimbeni, M. 2005. Information literacy and quality assurance in South African higher education institutions. Libri, 55(I):3I-38.

De Jager, K., Nassimbeni, M. \& Underwood, P. 2007. South Africa. In: Lau, J. Information Literacy: an international state-of-the art report. $2^{\text {nd }}$ draft. [Online]. www.uv.mx/usbi_ver/unesco. Accessed 9 March 2010.

Eisenberg, M., Lowe, A. \& Spitzer, K. 2004. Information: essential skills for the information age. Westport, Conn: Library Unlimited.

Feast, V. 2003. Integration of information literacy skills into business courses. Reference Services Review, 3I(I):8I-95.

Fourie, I. 1999. Empowering the users-current awareness on the Internet. The Electronic Library, 17(6):379-388.

Grassian, E.S. \& Kaplowitz, J.R. 200I. Information literacy instruction: theory and practice. New York: Neal-Schuman.

Harrison, J. \& Rourke, L. 2006. The benefits of buy-in: integrating information literacy into each year of an academic programme. Reference Services Review, 34(4):599-606.

SA JnI Libs \& Info Sci 2010, 76(I) 
Haycock, K. 2000. What all librarians can learn from teacher librarians: Information literacy a key connector for libraries. In: Booker, D. (ed.) Concept, challenges, conundrum: from library skills to information literacy: Proceedings of the Fourth National Information Literacy Conference, 3-5 December, 1999. Adelaide: University of South Australia, pp. 24-25.

Johnson, B. \& Webber, S. 2003. Information literacy in higher education: a review and case study. Studies in Higher Education, 28(3):335-352.

Lwehabura, M.J. 2007. The status and practice of information literacy for teaching and learning in four selected Tanzanian Universities. Unpublished PhD dissertation. Pietermariztburg: University of Kwa-Zulu-Natal.

Lwehabura, M.J. \& Stilwell, C. 2008. Information literacy in Tanzanian university. Journal of Librarianship and Information Science, 40(3):|79-|9|.

McCaskie, L. 2004. What are the Implications for information literacy training in higher education with the introduction of federated search tools? Unpublished Masters Dissertation. [Online]. http://dagda.shef.ac.uk/dissertations/2003-04/External/ McCaskie Lucy MAlib.pdf. Accessed 19 March 2009.

Machet, M. \& Wessels, N. 2006. Family literacy projects and public libraries. Innovation, 32:56-73.

Myburgh, S. 2009. Literacy in Africa as a gateway to eradicating poverty. [Online]. http://www.helium.com/items/I007373litearcy-in-africa-as-a-gateway-to-eradicating-poverty. Accessed 19 February 2009.

Rasaki, O.E. 2008. A comparative study of credit earning information literacy skills courses of three African universities. [Online]. Library Philosophy and Practice. Available at: http://unlib.edu/LPP/rasaki.htm. Accessed 9 March 2010.

Rockman, I.F. 2006. Introduction: the importance of information literacy. [Online]. http://media.wiley.com/product_data/excerpt/ 78/07879652/0787965278.pdf. Accessed 27 October 2009.

Skagen, T., Torras, M.C., Blaabjerg, N.J. \& Hansen, T.V. 2006. Empowering students through information literacy in the physical and virtual classrooms: cross-institutional collaboration between library and faculty and between two Scandinavian university libraries. [Online]. www.ck-iv.dk/papers/SkagelBlaabjergTorrasHansen/Empowering/students/through/ information/litearcy.pdf. Accessed 27 October 2009.

Underwood, P.G. 2000. Unfinished business: the INFOLIT project of the Adamastor Trust. Innovation, 2I:I 5-2I.

Underwood, P.G., Nassimbeni, M. \& de Jager, K. 2002. South Africa: a case study in development through information literacy. Cape Town: University of Cape Town.

UNESCO. 2008. Towards information literacy indicators. Paris: UNESCO.

UNESCO. 2009. UNESCO and information literacy. [Online]. http://portal.unesco.org/ci/en/ev.php-URL_ID $=198 / 2 \& U R L \_D O=$ DO TOPIC\&URL SECTION=20I.html. Accessed 23 January 2009.

UNESC̄O Institute for Statistics. 2002. 2000 illiteracy rates - sub-Saharan Africa. [Online]. http://www.uis.unesco.org/en/stats/ statistics/literacy2000.htm. Accessed 22 February 2009.

Wright, A.J. 2007. Pre-service preparation programmes for academic librarians for teaching information literacy. [Online]. http:/ /www.proquest.umi.com. Accessed 20 February 2009.

\section{Appendix I: IL topics taught in LIS departments in South Africa}

I. Defining Information Literacy

- What is information literacy

- Why is it important?

- What are the competencies of an information literate person (including Doyle attributes of an information literate person)?

- Where do these information literacy competencies come from?

2. Information sources and resources (including discussion of the information cycle).

- Books

- Periodicals

- Open Access

- The Internet

- Reference works

- Other sources

3. Portals, gateways and library websites

- Portals and gateways

- Library websites

4. Constructing a search query

- Concept identification

- Information retrieval systems

- Search engine mathematics

- Natural language queries

- Examples of query construction

5. Internet searching

- Directories

- Search engines

- Meta search engines

- Meta sites

- Google scholar

- Advanced Web searching 
6. Searching databases and online journals

- What is a database?

- What is an online journal?

- How to access databases and online journals

- How to choose an information resources

- How to search databases and platform

- How to use the iterative process to adapt a search query

- How to use search strategies

7. Organising and retrieving information on your computer

- What is personal information management (including taking notes, preparing mind maps etc)?

- How to organise information on your computer

- How to retrieve information on your computer

- The importance of organising and retrieving information on your computer.

8. Ethical and fair use of information

- What is ethics?

- What are intellectual property rights?

- What are patents and trademarks?

- Copyright

- Plagiarism

9. Referencing and referencing techniques (including citing and reasons for citations)

- What is referencing?

- Types of referencing styles/systems

- How to reference printed sources

- How to reference electronic sources

- How to reference other forms of non-print sources

- What are other styles of referencing?

10. Evaluating information and information sources

- What is the process of evaluating information and information sources?

II. Writing assignments and research reports

- What is scholarly communication and why is it important?

- What is an assignment?

- What is the process of writing assignments and research reports?

12. $21^{\text {st }}$ century communication

- What is social software?

- What is Web 2.0?

- What are blogs and wikis?

- What are social networks on the Internet?

- What is social bookmarking?

- What are social applications?

- What is Library 2.0?

- What are mobile computing and social networking?

- How to evaluate informal information and information sources

Appendix 2: Topics offered in IL programmes by academic libraries

I. Library Orientation

- Library tour

- Use of the catalogue

2. Special Collection Services

3. Information Retrieval/Information Problem Solving

- Defining the information task

- Identifying and locating information sources

- Selecting information sources

- Organizing and presenting information

- Evaluating the process and information selection

4. Database searching

5. References Services

SA JnI Libs \& Info Sci 2010, 76(I) 